\title{
ISOLATION OF TWO ACTIVE GLUCOSIDES, BRAXIN A1 AND A2, FROM RHIZOMES OF BRACKEN FERN
}

\author{
Toshiyuki SAITO and Daisuke MOCHIZUKI \\ Department of Veterinary Pharmacology, Faculty of Agriculture, \\ Tottori University, Koyama-cho, Tottori 680, Japan \\ Accepted October 30, 1985
}

\begin{abstract}
Two glucosides to enhance histamine release from rat peritoneal mast cells were isolated from rhizomes of bracken fern (Pteridium aquilinum (L.) Kuhn). by column chromatography on Sephadex LH-20 and droplet counter-current chromatography, and named braxin A1 and A2. They were $\beta$-glucopyranosides with an aromatic structure in the aglycone moiety. They were appreciably unstable in activity and chemical structure, and were different from the active glucoside in the young fronds. Braxin A1 and A2 may well be identical with the toxic principles responsible for the bracken poisoning.
\end{abstract}

Key words : Bracken fern, poisoning, toxin, histamine, mast cell.

\section{INTRODUCTION}

It has been demonstrated that bracken fern (BF), Pteridium aquilinum (L.) Kuhn, has acute and chronic toxicity in cattle (Evans et al., 1954: Umeda et al., 1963: Kitahara et al., 1968: Yamane et al., 1975a), so-called cattle bracken poisoning, and in guinea pigs (Maeda, 1975 : Morita et al., 1976 : Ushijima et al., 1983). BF also produces tumors in domestic (Pamukcu et al., 1967 : McCrea and Head, 1981 : Yoshikawa et al., 1981) and experimental animals (Evans and Mason, 1965 : Pamukcu and Price, 1969 : Hirono et al., 1970 : Pamukcu et al., 1972), and these neoplasms may be associated with the chronic toxicity. The studies on experimental induction of bracken poisoning have suggested that the toxic principles were unstable and not so strong toxicity when compared with well-known toxins, though serious poisoning resulted from a long term feeding the plant. However, the toxic principles in $\mathrm{BF}$ have not yet been identified, whereas a number of substances have been reported as carcinogens or mutagens.

On the other hand, it has been presumed that the release of histamine and heparin from mast cells would be associated with characteristic clinical findings, edematous and hemorrhagic changes with blood coagulation disorder, in cattle bracken poisoning. We

連絡先： $=680$ 鳥取市湖山町南 4-101 鳥取大学農学部・家畜薬理学講座 斎藤 俊之 
demonstrated that the fractions from the fronds (Ishii et al., 1974) and rhizomes (Ishii et al., 1979: Saito et al., 1979) of BF enhanced the release of histamine from rat peritoneal mast cells, and that the glucoside fraction from the young fronds produced edema and hemorrhage of the urinary bladder in guinea pigs (Saito et al., 1982), so it may be responsible for the toxicity in cattle. Recently, we succeeded in the isolation of a glucoside from the toxic glucoside fraction, and demonstrated that this glucoside enhanced the release of histamine from rat mast cells (Saito et al., 1984). On the other hand, it has been suggested that the rhizomes might be more toxic for cattle than the fronds (Evans, et al., 1961 : Kitahara, 1974). Recently, we suggested that the histamine releasing substances in the rhizomes would be glucosides (Saito et al., 1979), structurally somewhat different from those in the fronds (Saito et al., 1984).

This paper deals with a method for the isolation of the histamine releasing substances from bracken rhizomes and their some chemical characteristics. Two active glucosides, braxin A1 and A2, were isolated by column chromatography on Sepadex LH20 and droplet counter-current chromatography.

\section{MATERIALS AND METHODS}

Extraction and partition : The rhizomes of fresh BF were collected from the Mitani farm in a rural area of Tottori City in Japan, where bracken poisoning in cattle has occurred. The plants were immediately washed and stored at $-20^{\circ} \mathrm{C}$ in freezer. The stored rhizomes were freeze-dried and milled to a fine powder before use. About $2.7 \mathrm{~kg}$ of the powder was obtained from $9.5 \mathrm{~kg}$ of raw material. In this experiment, solvents were degassed, equilibrated with nitrogen gas, and mixed with acetic acid $(0.06 \%)$ to prevent loss of activity. The successful procedures of extraction and fractionation are summarized in Fig. 1. One hundred grams of the dried powder were soaked in $350 \mathrm{ml}$ of ice-cold methanol for $2 \mathrm{hr}$. The suspension was poured into a glass column $(5.5 \times 100$ $\mathrm{cm}$ ) with a glass filter, and about 1 liter of the filtrate was collected by adding more methanol to the column. The filtrate was vacuum dried below $0^{\circ} \mathrm{C}$, and the resulting materials were suspended in $70 \mathrm{ml}$ of ice-cold $0.01 \mathrm{~N}$ acetic acid. After insoluble materials were removed by filtration, the filtrate was washed with equal volumes of ether 3 times to remove lipid soluble materials and then freeze-dried. The resulting residue was called the crude extract. The crude extract was partitioned between $50 \mathrm{ml}$ of $\mathrm{n}$-butanol and $50 \mathrm{ml}$ of water 3 times. The organic and aqueous phases were separately vacuum-dried below $0^{\circ} \mathrm{C}$, and the resulting residues were called the butanol extract and water extract. About $1.8 \mathrm{~g}$ of the butanol extract and about $6.8 \mathrm{~g}$ of the water extract were obtained from $100 \mathrm{~g}$ of the dried powder.

Column chromatography (CC) : Sephadex LH-20 (Pharmacia Fine Chemicals, Sweden), which seems to operate with a combination of adsorption and molecular sieving for glucosides, was used as a bed material for the purification and isolation. The Sephadex column $(2.5 \times 45-75 \mathrm{~cm})$ was equilibrated with ethanol containing $1 \%$ acetic acid. A sample was dissolved in a minimum volume of the ethanol, put on the 
column, and eluted with the ethanol in descending mode at a flow rate of $24 \mathrm{ml} / \mathrm{hr}$. The eluate was monitored at $313 \mathrm{~nm}$ using a UV monitor $(150 \mathrm{~B}$, Beckman Instruments, USA), and $4 \mathrm{ml}$ fractions were collected using a fraction collector (FC-80, Gilson, USA).

Droplet counter-current chromatography (DCC): The DCC developed by Tanimura et al. (1970) has recently been used in the preparative scale separation of polar compounds and isolation of various natural products (Hostettmann, 1980). In this experiment, DCC was done with the solvent system of $\mathrm{CHCl}_{3}-\mathrm{MeOH}-\mathrm{H}_{2} \mathrm{O}(5: 6: 4)$ using a droplet counter-current chromatograph (DCC-300, Tokyo-Rika, Japan). The columns $(0.2 \times 40$

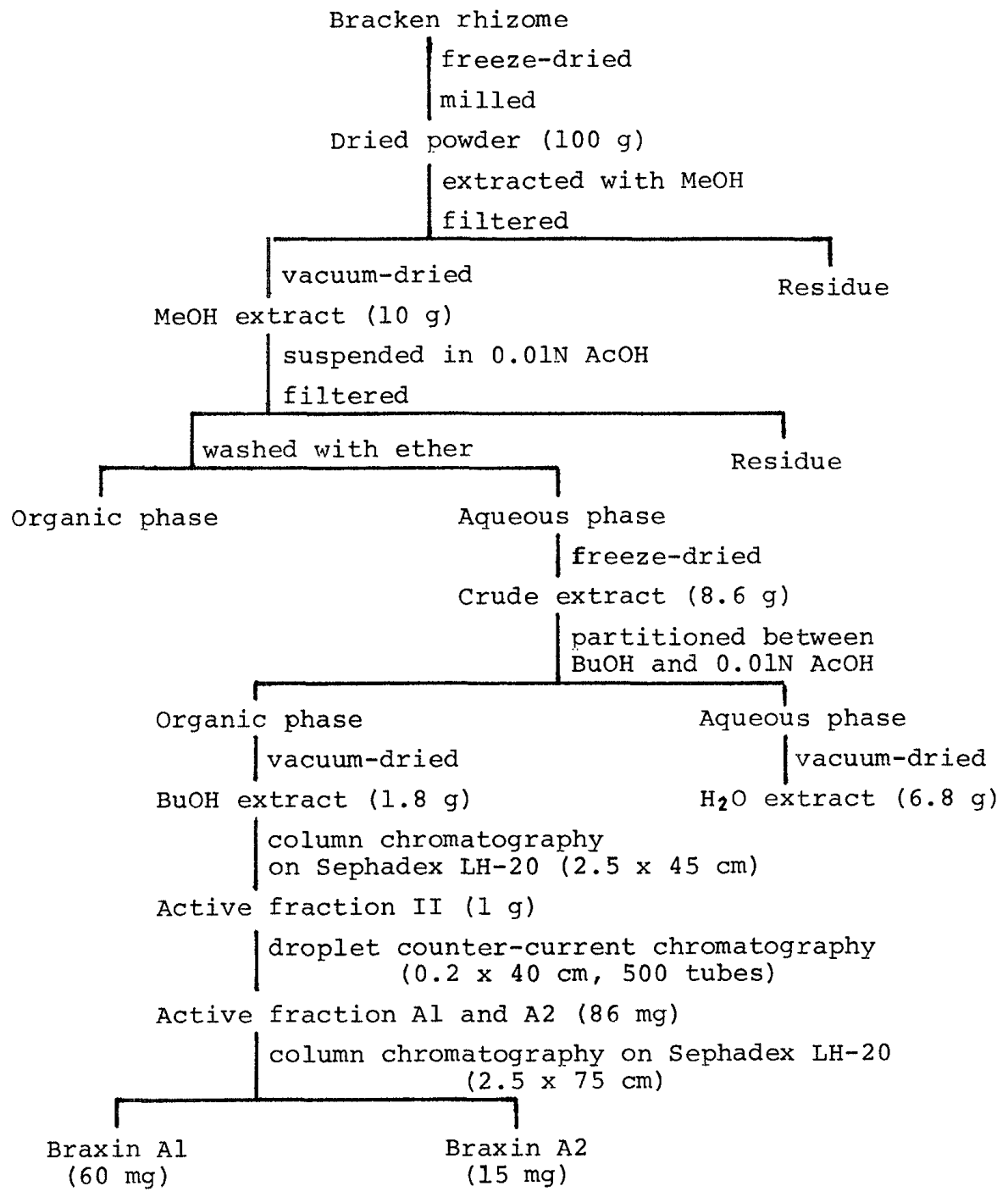

Fig. 1. Flow diagram of isolation procedure for active glucosides, braxin $\mathrm{A} 1$ and braxin $\mathrm{A} 2$, in bracken rhizome. 
cm, 500 tubes) connected in series with their Teflon tubes were filled with the upper layer solution as stationary phase. A sample was dissolved in $5 \mathrm{ml}$ of the upper layer solution, put on the column, and eluted with the lower layer in descending mode at a flow rate of $12 \mathrm{ml} / \mathrm{hr}$. The eluate was monitored at $313 \mathrm{~nm}$ using the $\mathrm{UV}$ monitor, and $4.5 \mathrm{ml}$ fractions were collected using the fraction collector.

Thin layer chromatography (TLC) : The purity in separated fractions was checked with TLC on silica gel (Wako FM plate, Wako Pure Chemical, Japan), developing with $\mathrm{CHCl}_{3}-\mathrm{MeOH}-0.01 \mathrm{~N}$ AcOH $(7: 3: 1$, lower layer). The glucosides were detected as colored spots by UV irradiation (PAN UV-LAUP, Tokyo-Kougaku, Japan).

Paper chromatography (PC): To identify the sugar in the isolated active glucosides, they were treated with an enzyme, $\beta$-glucosidase (sweet almond, P-L Biochemical, USA). The hydrolysates were put on filter paper (No.50, Toyo, Japan) and developed with $\mathrm{BuOH}-\mathrm{AcOH}-\mathrm{H}_{2} \mathrm{O}(4: 1: 5$, upper layer), and sugar spots were detected with $\mathrm{AgNO}_{3}$ reagent.

The UV spectra of the active glucosides were measured with a spectrophotometer (124, Hitachi, Japan).

Measurement of histamine release : Wistar albino rats of either sex (200-300 g) were anesthetized with ether and exsanguinated. Eight $\mathrm{ml}$ of modified Hanks solution containing $0.1 \%$ bovine serum albumin, adjusted to $\mathrm{pH} 7.1$ with $\mathrm{NaHCO}_{3}$, was injected into the peritoneal cavity. The peritoneal washings were passed through a metallic fine mesh filter (pore size $25 \mu \mathrm{m}$ ) to remove debris and clumps of cells, and collected in an ice-cold polycarbonate tube. Purified mast cells were used in this experiment, although we used mixed peritoneal cells in the previous experiments (Ishii, et al., 1974, 1979 : Saito, et al., 1979, 1984). Mast cells were isolated by a Ficoll density gradient centrifugation by the method of Thon and Uvnäs (1966) with the following minor modifications. Ficoll (molecular weight 400,000, Pharmacia Fine Chemicals, Sweden) was dissolved in Hanks solution containing $0.1 \%$ bovine serum albumin. The washings (approximately $7 \mathrm{ml}$ ) were layered onto a discontinuous Ficoll gradient consisting of $\mathbf{3 0}$ and $40 \%$ Ficoll solutions. The gradients were left for $30 \mathrm{~min}$ at $4^{\circ} \mathrm{C}$ in a polycarbonate tube and then centrifuged at $360 \times \mathrm{g}$ for $10 \mathrm{~min}$. The mast cells were collected from the diffuse band at the interface between the two concentrations of Ficoll, and washed twice with $7 \mathrm{ml}$ of a buffered isotonic salt solution of the following composition $(\mathrm{mM})$ : $\mathrm{NaCl}, 145 ; \mathrm{KCl}, 2.7 ; \mathrm{CaCl}_{2}, 0.9$; bovine serum albumin, $0.1 \%$, adjusted to $\mathrm{pH} 7.1$ with $10 \%$ Sörensen phosphate buffer $\left(\mathrm{Na}_{2} \mathrm{HPO}_{4}+\mathrm{KH}_{2} \mathrm{PO}_{4}, 67 \mathrm{mM}\right)$ and by centrifugation at $265 \times \mathrm{g}$ for $5 \mathrm{~min}$. The mast cells were finally suspended in $2.3 \mathrm{ml}$ of ice-cold Hanks solution to give $4-5 \times 10^{5} \mathrm{cells} / \mathrm{ml}$. Microscopic observation showed that more than $95 \%$ of cells were mast cells.

The cell suspensions $(0.2 \mathrm{ml})$ were incubated in polycarbonate tubes at $37^{\circ} \mathrm{C}$ for 3 min, then test materials diluted in $0.2 \mathrm{ml}$ of Hanks solution were added and incubated at $37^{\circ} \mathrm{C}$ for $10 \mathrm{~min}$. The reaction was then stopped by adding $4 \mathrm{ml}$ of ice-cold buffer salt solution and each tube was centrifuged at $470 \times \mathrm{g}$ for $5 \mathrm{~min}$. After the supernatant was 
decanted, the cell pellet was resuspended in $1 \mathrm{ml}$ of $0.4 \mathrm{~N} \mathrm{HClO}_{3}$ to release residual histamine. To each suspension was added another $3 \mathrm{ml}$ of distilled water, and the tubes were centrifuged at $1600 \times \mathrm{g}$ for $10 \mathrm{~min}$. The supernatant $(0.5 \mathrm{ml})$ was used for the assay of histamine. Histamine was determined by the fluorescence method of Shore et al. (1959), omitting the purification procedures for histamine which are unnecessary in this system (Diamant and Krüger, 1967). The histamine release was expressed as a percentage of the total histamine content in the initial cell suspension $\left(2-3 \mu \mathrm{g} / 0.8-1 \times 10^{5}\right.$ cells). The spontaneous release of histamine observed in the absence of agents has been deducted from all values presented. Regression lines in Figures were calculated according to the least squares method.

\section{RESULTS}

Preparation of active fractions: The bracken rhizome powder was extracted with ice-cold methanol containing $\mathbf{0 . 0 6 \%}$ acetic acid, and the methanol extract suspended in $0.01 \mathrm{~N}$ acetic acid and then washed with ether (Fig. 1). About $9 \mathrm{~g}$ in dry weight of the crude extract was obtained from $100 \mathrm{~g}$ of the bracken powder. The crude extract was

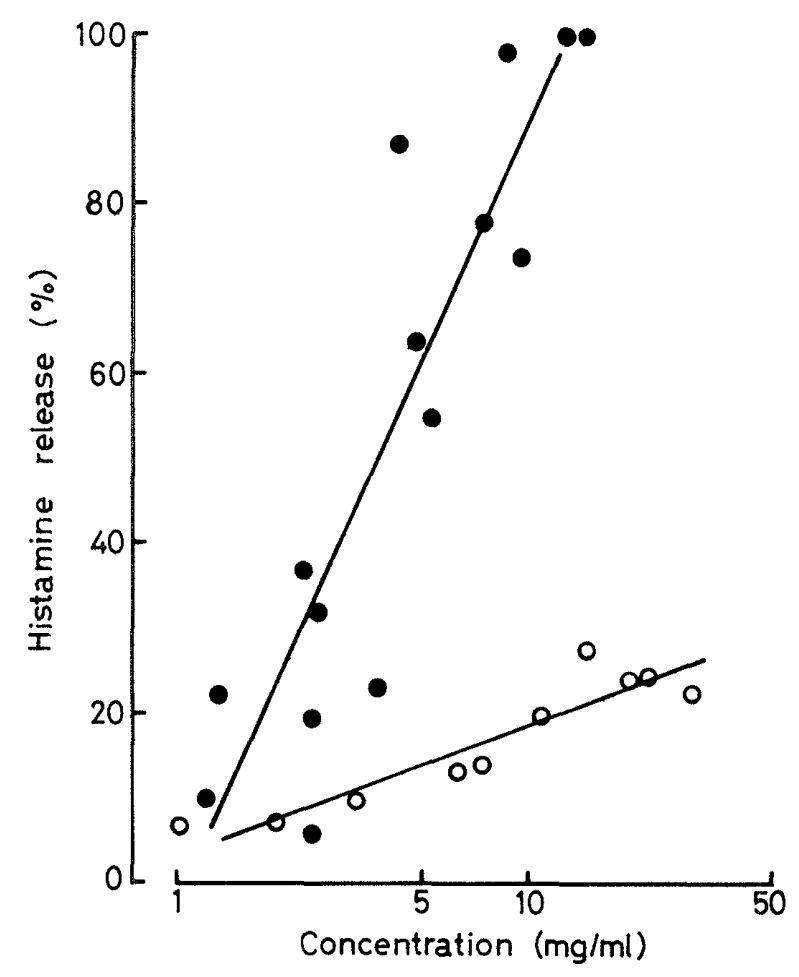

Fig. 2. Log dose-response for the histamine release from isolated rat mast cells stilulated with the butanol extract $(\bullet)$ and water extract $(O)$ obtained from the crude extracts by partition between $\mathrm{n}$-butanol and $0.01 \mathrm{~N}$ acetic acid. The histamine release with the crude extract $(30 \mathrm{mg} / \mathrm{ml})$ was $46.6 \pm 6.3 \%$ and spontaneous histamine release was $4.5 \pm 0.8 \%$ (mean \pm S. E. in 6 experiments, respectively). 
partitioned between $\mathrm{n}$-butanol and $0.01 \mathrm{~N}$ acetic acid, and both organic and aqueous phase solutions were separately vacuum-dried below $0^{\circ} \mathrm{C}$. These fractions were examined for histamine releasing activity. The butanol extract enhanced the release of histamine from rat mast cells, whereas the water extract had little effect even at a concentration of $40 \mathrm{mg} / \mathrm{ml}$ (Fig. 2). The yield in dry weight of the butanol extract was about $20 \%$ of the crude extract.

TLC analysis showed at least 13 different spots in the butanol extract. Samples of this extract were further fractionated with a Sephadex gel column $(2.5 \times 45 \mathrm{~cm})$. The eluate was monitored at $313 \mathrm{~nm}$ and was divided into 4 fractions (I, II, III, and IV) (Fig. 3). The mean yields of each fraction were about $0.02,56.28,7.74$, and $3.48 \%$ in dry weight of the applied butanol extract ( 5 experiments), respectively. In these fractions, most of the histamine releasing activity was recovered in fraction II, the other fractions having little or none (Fig.4).

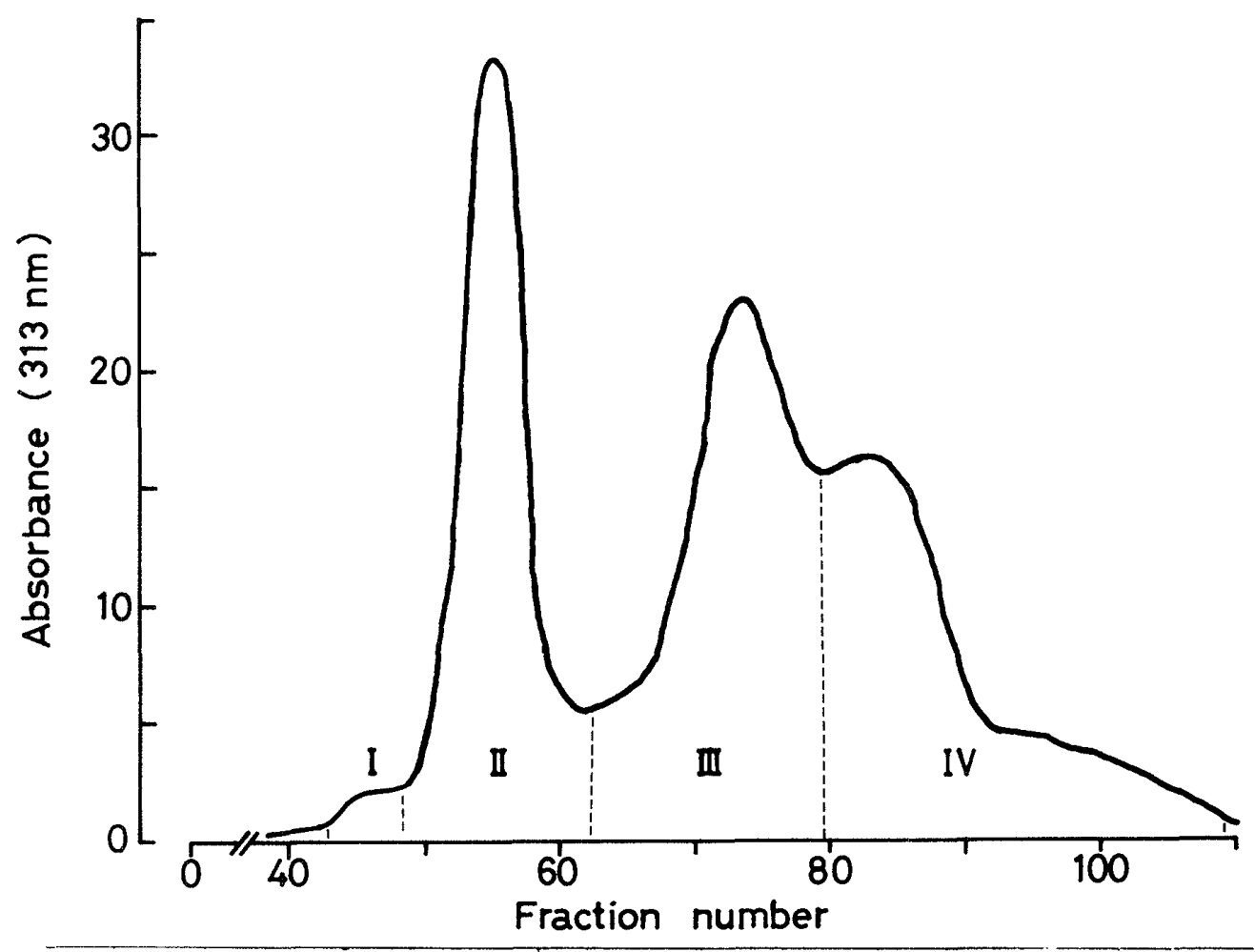

Fig. 3. Elution diagram of the butanol extract on column chromatography with Sephadex LH-20. The column $(2.5 \times 45 \mathrm{~cm})$, with $1.8 \mathrm{~g}$ of sample applied, was eluted with ethanol contained $1 \%$ acetic acid at the flow rate of $24 \mathrm{ml} / \mathrm{hr}$. Fractions of $4 \mathrm{ml}$ each were collected. The eluate was divided into 4 fractions (I, II, III, and IV) for assay of their histamine-releasing activities. 


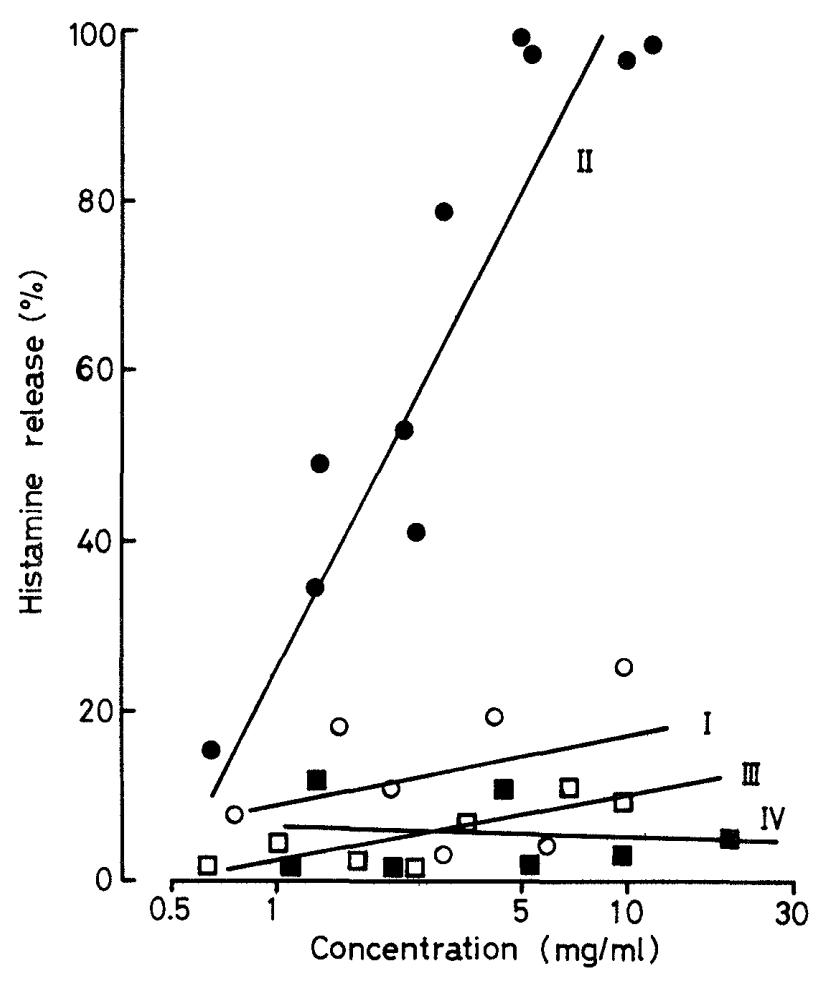

Fig. 4. Log dose-resposne for the histamine release from isolated rat mant cells stimulated with fraction I $(\bigcirc)$, II $(\bullet)$, III ( $\square)$, and IV $(\square)$ on column chromatography. Spontaneous histamine release was $5.6 \pm 1.3 \%$ (mean \pm S. E. in 6 experiments).

Isolation of active glucosides: Droplet counter-current chromatography (DCC) for fraction II produced an eluate with six different peaks at $313 \mathrm{~nm}$. (Fig. 5). The yield of total eluting materials was about $11 \%$ of the applied sample. Among the peak fractions tested, two had much activity to release of histamine from rat mast cells. The remaining materials in stationary phase were without activity even at concentrations of $50 \mathrm{mg} / \mathrm{ml}$. Two active fractions from the UV peak fractions (shaded parts in Fig. 5) were named braxin $\mathrm{A} 1$ and $\mathrm{A} 2$.

Samples of braxin A1 and A2 were purified further by CC on Sephadex LH-20 since TLC analysis showed them to be contaminated by small amounts of impurities. Each sample was dissolved in $1 \mathrm{ml}$ of ethanol, put on the Sephadex column $(2.5 \times 75 \mathrm{~cm})$ and eluted with ethanol containing $1 \%$ acetic acid, independently. Braxin A1 and A2 were able to isolate with less loss of activity by this chromatographic technique, whereas their activity were definitely decreased when eluted without acetic acid. 


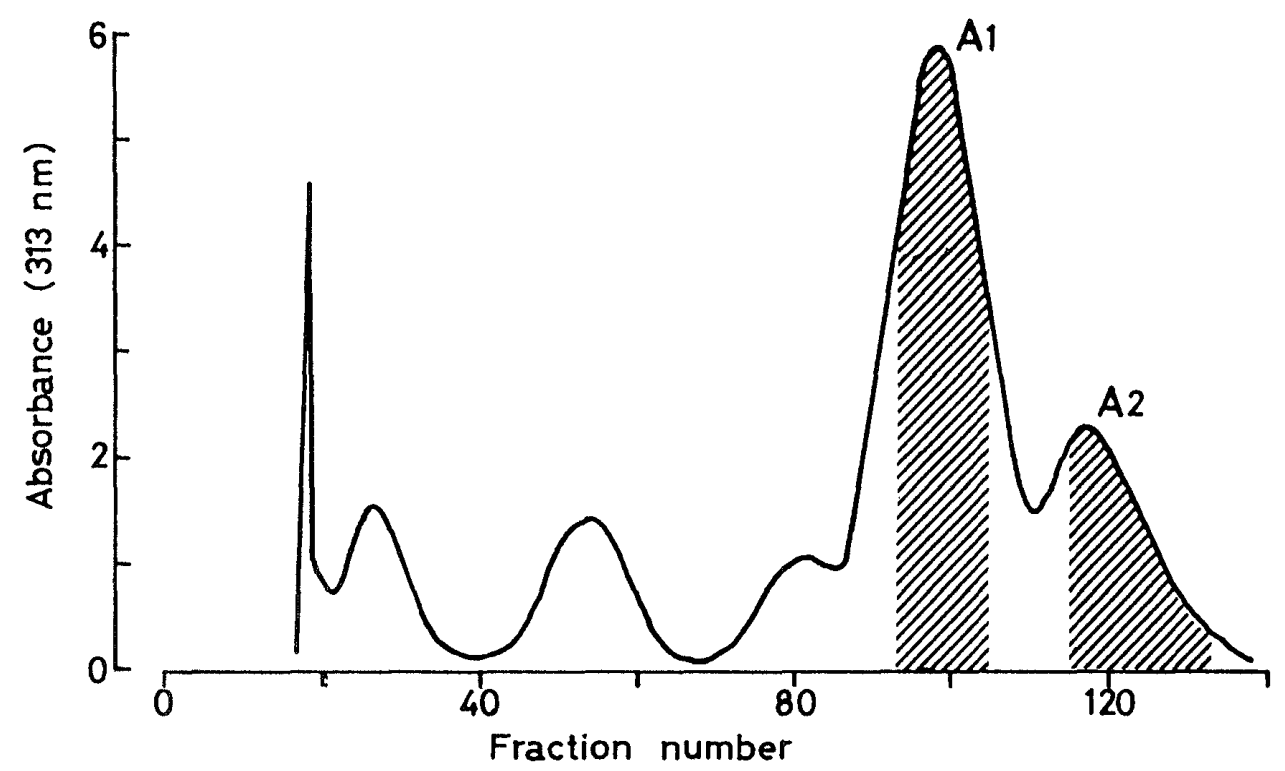

Fig. 5. Elution diagram of the active fraction (II) on droplet counter-current chromatography. Column, $0.2 \times 40 \mathrm{~cm}, 500$ tubes; Sample, $988 \mathrm{mg}$ of II; Solvent system, $\mathrm{CHCl}_{3}-\mathrm{MeOH}-0.01 \mathrm{~N}$ AcOH (5: $\left.8: 6: 4\right)$; Mobile phase, lower layer ; Flow rate, $12 \mathrm{ml} / \mathrm{hr}$; Fraction volume, $4.5 \mathrm{ml}$. Shaded parts indicate almost pure braxin A1 (A1) and braxin A2 (A2), respectively.

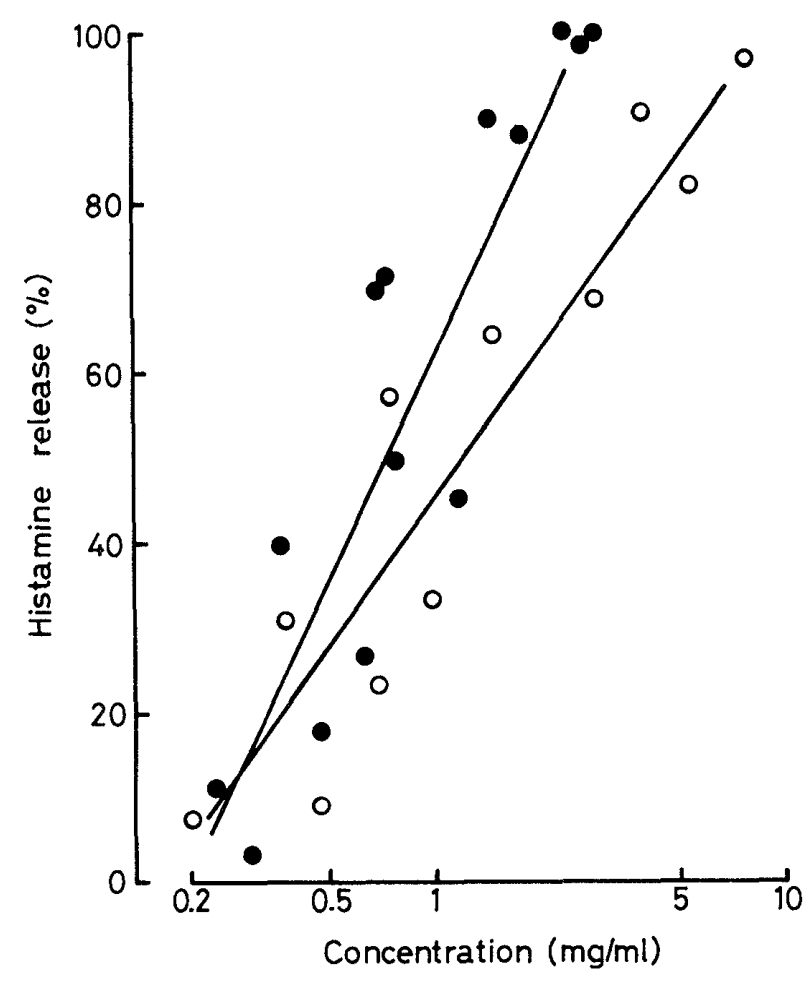

Fig. 6. Log dose-response for the histamine release from isolated rat mast cells stimu-

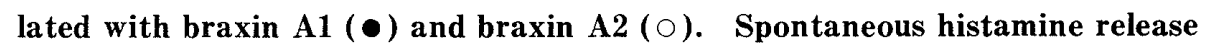
was $3.9 \pm 0.6 \%$ (mean $\pm S$. E. in 6 experiments). 
Braxin A1 and A2 dose-dependently enhanced histamine release from rat peritoneal mast cells, though their activity was relatively variable in the lots (Fig. 6). In some experiments, the histamine releasing activity often decreased definitely in some lots of braxin $\mathrm{A} 2$. They were usually freeze-dried and stored at $-20^{\circ} \mathrm{C}$ in vacuum. Under these conditions their activity was maintained over 6 months, but gradually decreased when stored not in vacuum. The final yields of braxin A1 and A2 were about 0.06 and $0.015 \%$ of the original rhizome powder.

Some properties of braxin $A 1$ and $A 2$ : The purity of each isolated sample was checked by TLC. Braxin A1 and A2 were detected as red spots under a UV lamp with Rf of 0.1 and 0.55 , respectively. Despite the high purity of braxin A1, it often gave a spot corresponding to braxin A2 along with its own spot on chromatogram of TLC. During development on TLC, often braxin A1 also gave the same spots. The freezedried braxin A1 and A2 samples were both white amorphous powders, highly hygroscopic, and readily soluble in water, methanol, or ethanol. When these preparations were moistened, they became less soluble in water, and their activity was lost within a day.

A

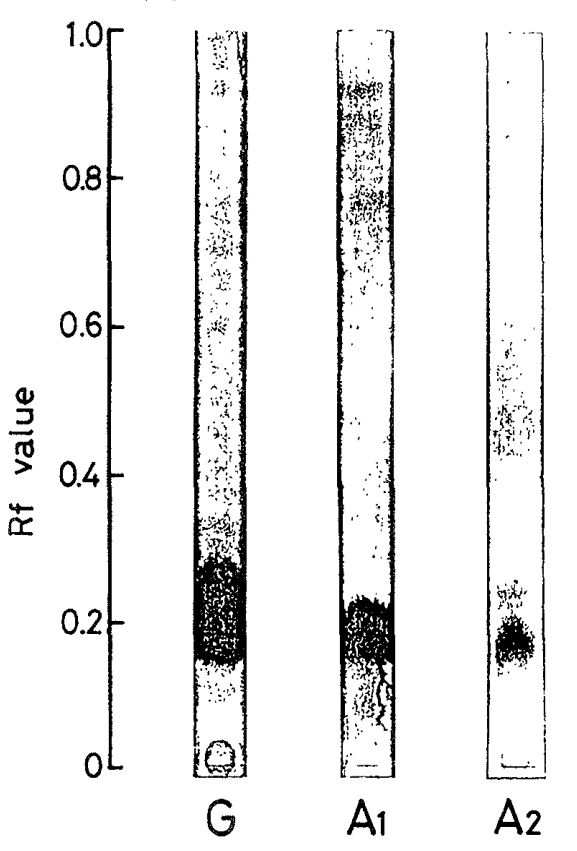

B

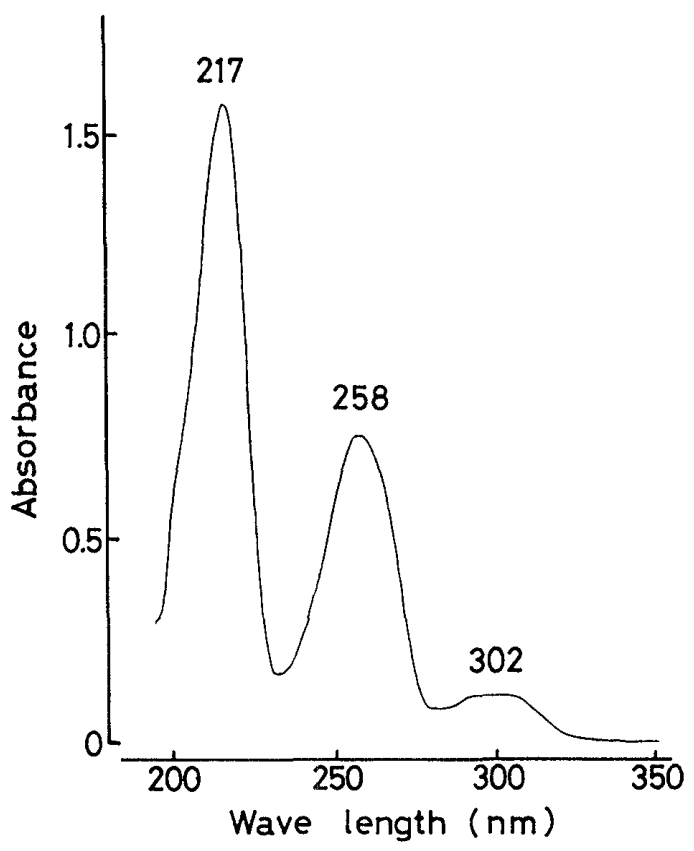

Fig. 7. A : Paper chromatograms of braxin A1 (A1) and A2 (A2) hydrolysed with $\beta$-glucosidase. G, D-glucose. Chromatogram developed with $\mathrm{BuOH}-\mathrm{AcOH}$ $\mathrm{H}_{2} \mathrm{O}$ (4: $1: 5$ upper layer). Glucide was detected with silve nitrate acetone. B : UV spectrum of braxin A1 (16 ng/ml). Solvent, $95 \%$ ethanol. 
The treatment of both braxin A1 and A2 with $\beta$-glucosidase gave a spot corresponding to that of D-glucose on the paper chromatogram (Fig. 7a). Braxin A1 and A2 has closely similar UV spectra with three maxima at 217, 258 (strong), and 302 (weak) in water or methanol (Fig. 7b).

\section{DISCUSSION}

Both braxin A1 and A2 had D-glucose as a sugar component and closely similar UV spectra with absorption maxima at 217,258 , and $302 \mathrm{~nm}$, though they were obviously differentiated on TLC. These results suggest that they are similar $\beta$-glucopyranosides of which the aglucone moieties are almost the same aromatic compound. During development on TLC, braxin A1 gave a spot corresponding to A2 $(\mathrm{Rf}=0.55)$ along with its own spot ( $R f=0.1)$. This result suggest that part of braxin A2 is derived from A1 by some minor chemical changes during the purification procedures.

Mast cells respond to various agents or toxins and release histamine, heparin and other chemical madiators, though the secretory response causes in high doses compared with that of secretagogues on the secretory cells to release hormone or digestive enzymes. It is also known that many of these agents induce the histamine release in the relatively high concentration with concomitant cell disruption, whereas several calcium-and energy-dependent releasing agents like compound 48/80 or the ionophore A23187 induce the release in the more low concentration with degranulation. In the present experiments, the histamine releasing activity of both braxin $A 1$ and $A 2$ was less potent when compared with well-known releasing agents such as compound 48/80 or A23187. However, the level of the potency of both braxin A1 and A2 was similar to that of many other agents as an adverse action such as d-tubocurarine, nicotine and etc. In further studies we observed that mast cells exposed to braxin A1 were stained with trypan blue on vital staining and greatly swelled without degranulation (unpublished data). Braxin A1 and A2 seemed to have certain cytotoxic effects on the mast cell membrane, and this action may involved in histamine release from mast cells.

In the present experiments, both braxin $\mathrm{A} 1$ and $\mathrm{A} 2$ was relatively stable when only stored under vacuum at $-20^{\circ} \mathrm{C}$. They easily lost the histamine releasing activity in non-acidic milieu, or by moisture. These facts indicate that the active glucosides from the rhizomes are also very unstable even in mild conditions as in that from the fronds.

We have previously demonstrated that one of the histamine releasing substances in the fronds was a glucoside, and suggested that it was structurally somewhat different from those in the rhizomes (Saito et al., 1984). Now we have confirmed this: the isolated braxin $A 1$ and $A 2$ differ from the glucoside in the fronds in $\mathrm{UV}$ spectra and $\mathrm{Rf}$ values on TLC. In histamine releasing activity, the glucosides from the rhizomes $\left(E D 50=\right.$ about $\left.1 \times 10^{-3} \mathrm{~g} / \mathrm{ml}\right)$ are much more potent than that from the fronds (ED25 $=$ about $1.5 \times 10^{-2} \mathrm{~g} / \mathrm{ml}$ ). However, this comparison needs further investigations because of different activity loss between them during the purification.

The cattle bracken poisoning is known to be induced by the long term feeding of the 
fronds or the rhizomes of $\mathrm{BF}$, and the experimental studies demonstrated the induction of similar symptoms in guinea pigs by feeding or oral administration of relatively large amount of BF (Maeda, 1975 : Morita et al., 1976 : Saito et al., 1982 : Ushijima et al., 1983). Experimental studies have also suggested that similar or identical compounds involved in bracken poisoning in both the animals, but the bracken toxins have not yet been identified. It was recently reported that ptaquiloside induced granulocytopenia and thrombopenia in a calf (Hirono et al., 1984b). On the other hand, it has also been found that the blood levels of histamine (Evans, 1968), heparin (Evans and Howell, 1962 : Evans, 1968), and heparin-like substances (Yamane et al., 1975b) rose in experimental bracken poisoning in cattle. The present results suggest that an increased release of histamine from mast cells may causes an increased vascular permeability and often edema and consective hemorrhage in various tissues. Actually, our previous study demonstrated that an oral administration of the glucoside fraction from the fronds reproduced the similar symptoms in guinea pigs (Saito et al., 1982). In this experiment, the histamine releasing action was detectable only in braxin $A 1$ and $A 2$ among the crude extracts from bracken rhizomes. These results indicate that releases of histamine, heparin and other chemical madiators from mast cells by the active glucosides in the fronds or rhizomes may be involved in the development of clinical symptoms such as edema and consecutive hemorrhage with blood coagulation disorder in the bracken poisoning.

$\mathrm{BF}$ is also carcinogenic in various animals, and chemical studies on the carcinogen have been done (Evans et al., 1982). Recently, ptaquiloside (Niwa et al., 1983: Hirono et al., 1984a) and aquilide A (Van der Hoeven et al., 1983), having almost the same structure, were reported as a carcinogen and mutagen in $\mathrm{BF}$, whereas the other components in BF such as shikimic acid (Evans and Osman, 1974), tannin (Wang èt al., 1976) and quercetin (Pamukcu et al., 1980) have once been suspected as the carcinogen. From the UV, IR, and NMR spectra analysis (unpublished data), it is suggested that braxin A1 and A2 clearly differ in chemical structure from ptaquiloside or aquilide $A$. We are now preparing a report on the identification of our active glucosides.

\section{ACKNOWLEDGEMENTS}

The authors are grateful to Drs. Shigehiro Hirano and Kazu Takeno of the University of Tottori, for their helpful suggestions and discussions, and to our colleagues who extend us their kind assistance.

\section{REFERENCES}

Diamant, B. and Krüger, P. G. (1967) : Histamine release from isolated rat peritoneal mast cells induced by adenosine-5'-triphoshate. Acta. physiol. scand., 71, 291-302.

Evans, W. C., Evans, E. T. R. and Hughes, L. E. (1954) : Studies on bracken poisoning in cattle. Part II. 1950. Bracken poisoning experjment (L luest farm). Br. Vet. J., 110, 365-380.

Evans, W. C., Evans, I. A., Axford, R. F. E. et al. (1961) : Studies on bracken poisoning in 


\section{Toshiyuki SAITO and Daisuke MOCHIZUKI}

cattle. Part VII. The toxicity of bracken rhizomes. Vet. Rec., 73, 852-853.

Evans, I. A. and Howell, R. M. (1962) : Bovine bracken poisoning. Nature, 194, 584-585.

Evans, I. A. and Mason, J. (1965) : Carcinogenic activity of bracken. Nature, 208, 913-914. Evans, I. A. (1968) : The radiomimetic nature of bracken toxin. Cancer Res., 28, 2252-2261.

Evans, I. A. and Osman, M. A. (1974) : Carcinogenicity of bracken and shikimic acid. Nature, 250, 348-349.

Evans, I. A., Prorok, J. H., Cole, R. C. et al. (1982): The carcinogenic, mutagenic and teratogenic toxicity of bracken. Proc. Royal Sci. Edinburgh, 81 B, 65-77.

Hirono, I., Shibuya, C., Fukushima, K. et al. (1970) : Studies on carcinogenic properties of bracken, Pteridium aquilinum. J. Natl. Cancer Inst., 45, 179-188.

Hirono, I., Yamada, K., Niwa, H., Shizuri, Y. et al. (1984a): Separation of carcinogenic fraction of bracken fern. Cancer Lett., 21, 239-246.

Hirono I., Kono, Y., Takahashi, K. et al. (1984b) : Reproduction of acute bracken poisoning in a calf with ptaquiloside, a bracken constituent. Vet. Rec., 115, 375-378.

Hostettmann, K. (1980): Droplet counter-current chromatography and its application to the preparative scale separation of natumal products. Planta med., 39, 1-18.

Ishii, K., Saito, T. and Sakatani, M. (1974) : Histamine releasing action of acetone dried powder of bracken fern on the rat peritoneal mast cells. J. Fac. Agr. Tottori Univ., 9, 27-33.

Ishii, K., Saito, T. and Kojima, H.(1979): Studies on the histamine releasing activity of bracken fern. I. Fractionation of the active ingredient by gel chromatography on Sepadex. Bull. Fec. Agr. Tottori Univ., 31, 134-139.

Kitahara, T., Yamaguchi, M., Fukushima, T.et al. (1968) : Experimental studies on bovine bracken poisoning. I. The first case. J. vet. Med., 471, 545-552.

Kitahara, T. (1974) : Experimental studies on bracken poisoning in cattle. Bull. Nippon Vet. Zootech. College, 23, 88-107.

Maeda, T. (1975) : Fundamental studies on the etiology of haematuria vesicales bovis. I. The induction of carcinomas and haemorrhages of the urinary bladder in guinea pigs by feeding bracken fern (Pteridium aquilinum). Bull. Fac. Agr. Tottori Univ., 27, 79-88.

McCrea, C. T. and Head, K. W. (1981): Seep tumours in North East Yorkshire. II. Experimental production of tumours. Br. vet. J., 137, 21-30.

Morita, Z., Senda, H., Yamamoto, Y. et al. (1976) : Studies on the toxic factor in bracken fern. II. Haemorrhagic changes in the urinary bladder of guinea pigs by feeding an ethanol extract of bracken fern. Bull. Fac. Agr. Tottori Unive., 28, 66-72.

Niwa, H. Ojika, M., Wakamatsu, K. et al. (1983) : Ptaquiloside, a novel norsesquiterpene glucoside from bracken, Pteridium aquilinum var. latiusculum. Tetrahedron Lett., 24, 4117-4120.

Pamukcu, A. M., Göksoy, S. K. and Price, J. M. (1967) : Urinary bladder neoplasms induced by feeding bracken fern ( pteris aquilina) to cows. Cancer Res., 27, 917-924

Pamukcu, A. M. and Price, J. M. (1969) : Induction of intestinal and urinary bladder cancer in rats by feeding bracken fern (Pteridium aquilinum). J. Natl. Cancer Inst., 43, 275-281.

Pamukcu A. M., Erturk, E., Price, J. M. et al. (1972) : Lymphatic leukemia and pulmonary tumors in female swiss mice fed bracken fern (Pteris aquilina). Cancer Res., 32, 1442-1445.

Pamukcu, A. M., Yalciner, S., Hatcher, J.F.et al. (1980) : Quercetin, a rat intestinal and 


\section{Active glucosides in bracken rhizome}

bladder carcinogen present in bracken fern (Pteris aquilina). Cancer Res., 40, 34683472 .

Saito, T., Ishii, K. and Okubo, Y. (1979) : Stdies on the histamine-releasing activity of bracken fern. II. Demonstration of glucosides in the active extract. Bull. Agr. Tottori Univ., 31, 140-147.

Saito, T., Ishii, K. and Goto, H. (1982) : Acute toxicity of bracken fern glucoside in glinea pigs. Bull. Fac. Agr. Tottori Univ., 34, 43-49.

Saito, T., Kirihara, Y. and Ishii, K. (1984) : Isolation of an active glucoside in bracken fern, Pteridium aquilinum. J. Toxicol. Sci., 9, 253-262.

Shore, P. A., Burkhal, A. and Cohn, V.H. (1959) : A method for the fluorometric assay of histamine in tissues. J. Pharmacol. exp. Ther., 127, 182-186.

Tanimura, T., Pisano, J. J., Ito, Y.et al. (1970) : Droplet countercurrent chronıatography. Science, 169, 54-56.

Thon, I. - L. and Uvnäs, B. (1966) : Mode of storge of histamine in mast cells. Acta physiol. scand., $67,455-470$.

Umeda, N., Watabe, K., Noguchi, S. et al. (1963) : Experimental studies on bracken poisoning in cattle. J. vet. Med., 360, 1090-1094.

Ushijima, J., Matsukawa, K., Yuasa, A. et al. (1983) : Toxicities of bracken fern in guinè pigs. Jpn. J. Vet. Sci., 45, 593-602.

Van der Hoeven, J. C. M., Lagerweij, W. J., Posthumus, M. A. et al. (1983) : Aquilide A, a new mutagenic compound isolated from bracken fern (Pteridium aquilinum (L.) Kuhn). Carcinogenesis, 4, 1587-1590.

Wang, C. Y., Chiu, C. W., Pamukcu, A. M. et al. (1976) : Identification of carcinogenic tannin isolated from bracken fern (Pteridium aquilinum). J. Natl. Cancer Inst., 56, 33-36.

Yamane, O., Hayashi, T., Sako,S., Kihara, T. et al. (1975a) : Studies on hemorrhagic diathesis of experimental bovine bracken poisoning. I. Detection of circulating anticoagulants. Jpn. J. Vet. Sci., 37, 335-340.

Yamane, O., Hayashi, T., Sako, S. et al. (1975b) : Studies on hemorrhagic diathesis of experimental bovine bracken poisoning. II. Heparin-like substance level in blood. Jpn. J. Vet. Sci., 37, 341-347.

Yoshikawa, T., Oyamada, T., Yoshikawa, H. et al. (1981) : Histopathogenesis of bracken ferninduced experimental tumor of urinary bladder. Jpn. J. Vet. Sci., 43, 875-885. 